\title{
Implementasi Penugasan Dosen Sekolah (PDS) di Perkuliahan untuk meningkatkan Berpikir Kreatif Mahasiswa Civic Education di Universitas Muhammadiyah Mataram
}

\author{
Maemunah', Abdul Sakban² Sri Rejeki ${ }^{3}$ \\ ${ }^{1}$ Pendidikan Pencasila dan Kewarganegaran, Universitas Muhammadiyah Mataram, Email: maemunahabdullah@gmail.com \\ ${ }^{2}$ Pendidikan Pencasila dan Kewarganegaran, Universitas Muhammadiyah Mataram, Email: sakban.elfath@yahoo.co.id \\ ${ }^{3}$ Pendidikan Pencasila dan Kewarganegaran, Universitas Muhammadiyah Mataram, Email: umi.cici.66@gmail.com
}

\section{INFO ARTIKEL \\ Riwayat Artikel: \\ Diterima: 26-September- 2019 \\ Disetujui: 28 Maret 2020}

\section{Kata Kunci:}

Implementasi

Penugasan

Sekolah

Berpikir

Kreatif

Perkuliahan

\section{Dosen}

\begin{abstract}
ABSTRAK
Abstrak: Kemampuan berpikir kreatif akan mendorong seseorang untuk senantiasa berinovasi, sehingga mahasiswa perlu dilatih untuk menumbuhkan ketrampilan. Tujuan penelitian ini menjelaskan implementasi Penugasan Dosen Sekolah (PDS) di perkuliahan untuk meningkatkan kreativitas berpikir mahasiswa civic education. Pendekatan kegiatan pelaksanaan PDS menggunakan deskripsi. Data-data yang dikumpulkan akan dideskripsikan secara mendalam dan terukur terkait dengan pembelajaran. Desain pembelajaran menggunakan desain penugasan dosen sekolah di perkuliahan dengan menerapkan metode pembelajaran presentasi, tanya jawab, The Power of Two, Group to Group Exchange dan penugasan. Hasil penelitian menunjukkan bahwa pelaksanaan implementasi PDS di perkuliahan dapat berdampak terhadap adanya pengembangan berpikir kreatif mahasiswa civic education dalam menemukan ide, gagasan, konsep, fakta, berkomunikasi, dan berinteraksi. Sementara proses pelaksanaan PDS di perkuliahan dapat dilakukan beberapa tahapan yaitu Pertama, merencanakan pelaksanaan PDS bersama dosen program studi; Kedua, menyiapkan perangkat pembelajaran berupa RPS, RPM, media pembelajaran, evaluasi; Ketiga, melakukan evaluasi; Keempat, merefleksikan hasil pembelajaran PDS di perkuliahan. Jadi adanya pembelajaran PDS dapat memberikan dampak berpikir kreatif mahasiswa, bertanggungjawab dan mampu mengkomunikasikan temua-temuan yang dapatkan ketika diskusi maupun saat presentasi.
\end{abstract}

\begin{abstract}
Creative thinking skills will encourage one always to innovate, so that students need to be trained to cultivate talents. The purpose of this research explains the implementation of School lecturer Assignment (PDS) in the course to increase the creativity of thinking civic education students. Approach to implementation of PDS using descriptions. The data collected will be genuinely described and measured about learning. The Learning design uses the design of The school lecturer assignments at the lecture by implementing The presentation learning methods; questions answered, The Power of Two, Group to Group Exchange, and duties. The results showed that the implementation of PDS implementation in the lecture could have an impact on the development of creative thinking of civic education students in finding ideas, ideas, concepts, facts, communicating, and interacting. While the process of implementation of PDS in the lecture can be done several stages, namely first, plan the implementation of PDS with the study program lecturer; Second, set up learning devices in the form of RPS, RPM, learning media, evaluation; Third, evaluate; Fourth, reflecting the results of PDS learning in the lecture. So the learning of PDS can impact the creative thinking of students, responsible and able to communicate the findings that get when the discussion or during the presentation.
\end{abstract}

\section{A. LATAR BELAKANG}

Kepribadian peserta didik belum terbina dengan baik, karakter keindonesiaan belum memenuhi standar pendidikan, pengetahuan tentang konsep-konsep PPKn masih kurang, penggunaan media yang digunakan oleh guru masih kurang tidak variatif, fasilitas kurang memadai menyebabkan kemampuan peserta didik tidak maksimal dalam memahami pembelajaran[1].
Sementara faktor lain pada mahasiswa yakni motivasi belajar mahasiswa kurang memuaskan, kurang inovatifnya mereka berpikir dalam menelaah sesuatu materi pembelajaran.

Beberapa kelemahan pokok PPKn di Indonesia[2], seperti (1) terlalu menempatkan aspek nilai moral dengan menempatkan peserta didik sebagai objek yang berkewajiban untuk menerima nilai-niai tertentu sehingga terkesan bersifat dogmatis; (2) kurang 
diarahkan pada pemahaman struktur, proses dan institusi-institusi negara dengan segala kelengkapannya; dan (3) dianggap terlalu berorientasi kepada kepentingan rezim yang sedang berkuasa.

Penelitian ini berawal dari penelitian tentang penugasan dosen sekolah, pada penugasan sekolah mengahasilkan perangkat pembelajaran, artikel ilmiah, video, jurnal refleksi, dan media pembelajaran [3]. Penugasan dosen di sekolah diwujudkan dengan produk dan pengembangan bahan ajar berbasis karakter [4]. Implementasi Pembelajaran melalui program penugasan dosen di kampus dapat meningkatkan kreativitas mahasiswa [5]. Yang sudah dilakukan penelitian sebelumnya adalah membuat perangkat pembelajaran, mengembangkan bahan ajar berbasis karakter, meningkatkan kreativitas, semua dilakukan dalam implementasi PDS di kampus. Sementara yang perlu dilakukan dalam penelitian ini adalah meningkatkan kemampuan berpikir kreativitas, kolaborasi, berpikir kritis, dan komunikasi mahasiswa Civic Education melalui implementasi Penugasan Dosen Sekolah (PDS) di perkuliahan.

Masalah berpikir kreativitas, kolaborasi, berpikir kritis, dan komunikasi mahasiswa menjadi alasan utama dilaksanakannya kegiatan penugasan dosen sekolah di kampus. Dalam pelaksanaannya mahasiswa belum mampu kreativitas berpikir mahasiswa berupa mengolah dan menelaah tugas yang diberikan pengajar secara efektif. Kolaboratif merupakan jalinan komunikasi antara kelompok satu dengan kelompok lainnya untuk saling menyampaikan informasi, data dan materi pembelajaran. Berpikir kritis yang terjadi belum efektif karena hanya sebagian saja yang mampu menerapkan, yang lainnya hanya berdiam saja. Komunikasi dibangun untuk saling menghargai dan menghormati antara mahasiswa satu dengan mahaiswa lainnya untuk meningkatkan saling menghargai dan bertoleransi.

Kemampuan berpikir kreatif akan mendorong seseorang untuk senantiasa berinovasi, sehingga mahasiswa perlu dilatih untuk menumbuhkan ketrampilan tersebut[6]. Kemampuan komunikasi, berpikir kreatif merupakan kemampuan yang sangat penting dimiliki oleh setiap siswa dalam pembelajaran. Pembelajaran berbasis masalah merupakan salah satu alternatif pembelajaran yang dapat diterapkan di kelas untuk meningkatkan kemampuan tersebut. Dalam pembelajaran ini siswa dituntut berkomunikasi dan kreatif dalam mengemukakan idenya[7].

Berpikir kreatif memiliki lima aspek atau indikator[8]. Pertama, fluency (kelancaran), meliputi kemampuan untuk mengeluarkan banyak ide, cara, saran, pertanyaan, gagasan ataupun alternatif jawaban dengan lancar dalam waktu tertentu. Kedua, flexibility (keluwesan), meliputi kemampuan mengeluarkan gagasan, jawaban atau pertanyaan yang bervariasi dimana gagasan atau jawaban tersebut diperoleh dari sudut pandang yang berbeda-beda dengan mengubah cara pendekatan atau pemikiran. Ketiga, originality (keaslian), merupakan kemampuan mengeluarkan ungkapan, cara, gagasan, atau ide untuk menyelesaikan masalah atau membuat kombinasi bagian-bagian atau unsur secara tidak lazim, unik, baru yang tidak terpikirkan oleh orang lain. Keempat, elaboration (merinci), merupakan kemampuan untuk memperkaya, mengembangkan, menambah, menguraikan atau merinci detail-detail dari objek, gagasan, ide, produk atau situasi sehingga lebih menarik. Kelima, metaphorical thinking (berpikir metafora), merupakan kemampuan untuk menggunakan perbandingan atau analogi untuk membuat keterkaitan baru. Berpikir metafora termasuk dengan berpikir tentang bagaimana suatu hal yang berbeda tampak serupa atau berbeda kemudian mengarahkan keterkaitan ini untuk menghasilkan atau menemukan kemungkinankemungkinan baru.

Keterampilan berpikir kreatif merupakan keterampilan berpikir tingkat tinggi, yang harus diberdayakan dalam pendidikan karena merupakan komponen penting dalam pengembangan ilmu pengetahuan dan teknologi. Peningkatan keterampilan berpikir kreatif dapat diintegrasikan dalam kurikulum yang implementasinya melalui kegiatan pembelajaran[1].

Dengan adanya pelaksanaan PDS di perkuliahan dapat memberikan dampak yang positif untuk meningkatkan perubahan dalam pembelajaran di kampus, karena PDS ini dalam pembelajaran lebih berpusat pada mahasiswa, penggunaan media pembelajaran, pemberian lembar kegiatan setiap kelompok mahasiswa. Selain itu, mahasiswa dapat menemukan sendiri olah pikirnya apabila diberikan tugas individu maupun kelompok tentang topik-topik yang didiskusikan setiap pertemuan. Demikian pula pelaksanaan PDS ini merupakan kegiatan yang efektif dalam memperbaiki kinerja pembelajaran baik di sekolah maupun di kampus[9]. Kegiatan PDS ini membuat dosen dan guru bekerja sama dalam pelaksanaan proses pembelajaran. Selain itu, mereka juga berkalaborasi dalam penelitian, sehingga guru-guru yang kurang paham dalam penelitian akan dibantu oleh dosen. Begitu pula dosen yang mengajar di kelas akan dibantu oleh guru dalam pelaksanaan pembelajaran karena guru lebih paham karakteristik siswa di sekolah[10].

Hasil penelitian sebelumnya lebih fokus pada implementasi perangkat pembelajaran, pengembangan bahan ajar berbasis karakter dan meningkatkan berpikir kreatif mahasiswa, maka kelemahan yang belum diteliti orang lain adalah meningkatkan berpikir kreatif mahasiswa civic education. Perbedaan dengan hasil penelitian kami adalah meningkatkan perubahan dalam pembelajaran di kampus, dalam pembelajaran lebih berpusat pada mahasiswa, penggunaan media 
pembelajaran, pemberian lembar kegiatan setiap kelompok mahasiswa sehingga mahasiswa mampu berpikir kreatif. Dengan demikian tujuan penelitian untuk menjelaskan implementasi PDS di perkuliahan untuk meningkatkan kreativitas berpikir mahasiswa Civic Education di Universitas Muhammadiyah Mataram.

\section{B. METODE PENELITIAN}

1. Jenis Penelitian

Penelitian ini termasuk penelitian kualitatif. Penelitian ini bertujuan menguraikan fakta, peristiwa dan perilaku masyarakat yang berkaitan dengan pelaksanaan PDS di perkuliahan.

2. Pendekatan dan Desain Pembelajaran

Pendekatan kegiatan pelaksanaan PDS menggunakan deskripsi. Data-data yang dikumpulkan akan dideskripsikan secara mendalam dan terukur terkait dengan pembelajaran. Desain pembelajaran menggunakan desain penugasan dosen sekolah di perkuliahan dengan menerapkan metode pembelajaran presentasi, tanya jawab, The Power of Two, Group to Group Exchange dan penugasan pada mata kuliah Pengantar IPS semester ganjil program studi Pendidikan Pacasila dan Kewarganegaraan Fakultas Keguruan dan Ilmu Pendidikan Universitas Muhammadiyah Mataram selama 2 bulan mulai tanggal 2 September sampai denga 30 Oktober 2019 dengan jumlah responden 23 orang.

Berikut alur pelaksanaan PDS di perkuliahan, yaitu:

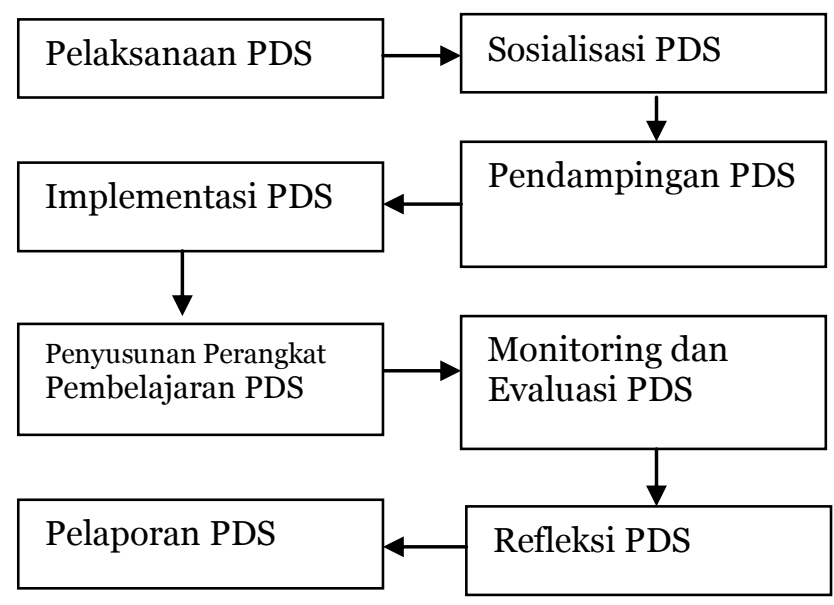

Gambar 1. Alur Implementasi PDS di Perkuliahan

\section{Metode Pengumpulan Data}

Metode pengumpulan data dalam penelitian ini menggunakan observasi, interview, non tes dan dokumentasi. Data sekunder yang dibutuhkan dalam kegiatan PDS ini adalah artikel, buku ajar, media pembelajaran. Sedangkan data primer digunakan untuk melakukan interview secara langsung kepada responden untuk melihat sejauhmana dan pengalaman mereka setelah diberikan pembelajaran PDS.

\section{Teknik Analisa Data}

Teknik analisis menggunakan model interaktif analisis.

\section{HASIL DAN PEMBAHASAN}

\section{Proses Pelaksanaan PDS di perkuliahan}

Proses pelaksanaan PDS di perkuliahan dapat dilakukan beberapa tahapan yaitu Pertama, merencanakan pelaksanaan PDS bersama dosen program studi; Kedua, menyiapkan perangkat pembelajaran berupa RPS, RPM, media pembelajaran, evaluasi; Ketiga, melakukan evaluasi; Keempat, merefleksikan hasil pembelajaran PDS di perkuliahan.

a. Perencanaan

Perencanaan dilakukan sebelum perkuliahan dilaksanaakan, dengan tujuan pembahasan terkait pembahasan tujuan pembelajaran, indicator, kegiatan awal, kegiatan inti dan kegiatan akhir serta media pembelajaran yang dipergunakan. Perencanaan melibatkan dosen program studi, dilakukan untuk mendengarkan masukan, saran untuk perbaikan alat peraga, media pembelajaran yang akan digunakan oleh dosean PDS di perkuliahan.

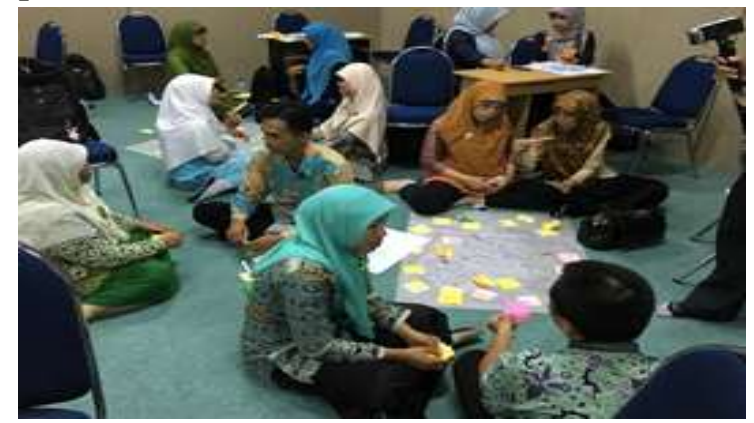

Gambar 2. Proses diskusi bersama dosen program studi

b. Persiapan

Persiapan yang dilakukan dalam pelaksanaan PDS adalah menyiapkan perangkat pembelajaran berupa rencana pembelajaran semester, rencana pembelajaran mingguan, media pembelajaran berupa media gambar, animasi, LK, dan internet. Evaluasi hasil kinerja mahasiswa, dan penilaian sikap mahasiswa.

c. Evaluasi

Evaluasi merupakan monitor terkait dengan dampat hasil pembelajaran selama beberapa pertemuan melalui tugas individu dan tugas kelompok untuk diberikan penilaian.

d. Refleksi

Refleksi dilakukan untuk melihat kembali apa saja kesan dan pesan yang dialami dosen selama proses pembelajaran yang dilakukan oleh tim evaluasi hibah PDS melalui isian angket dan lembar interview.

\section{Implementasi PDS di perkuliahan}

Adapun hasil implementasi PDS di perkuliahan dapat digambarkan berikut ini:

a. Kemampuan berpikir kreatifitas mahasiswa sangat bervariatif 


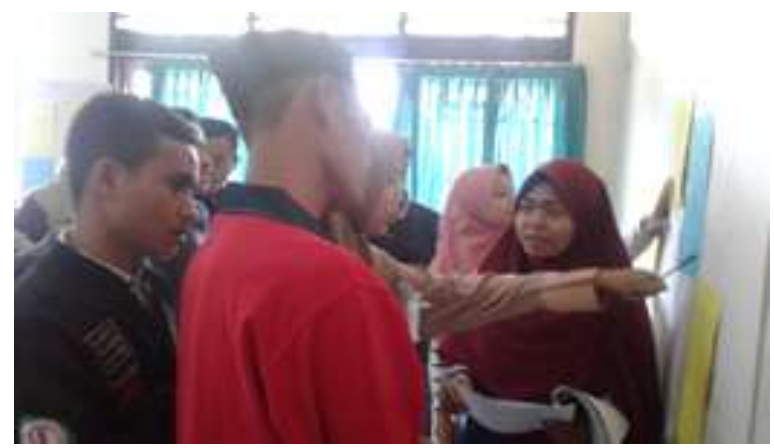

Gambar 3. Mahasiswa menjelaskan hasil LK

Gambar tersebut menunjukkan bahwa mahasiswa mampu menemukan pendapat secara mandiri dan mampu berkomunikasi dengan baik serta mampu menjelaskan kepada teman lainnya secara kolaboratif.

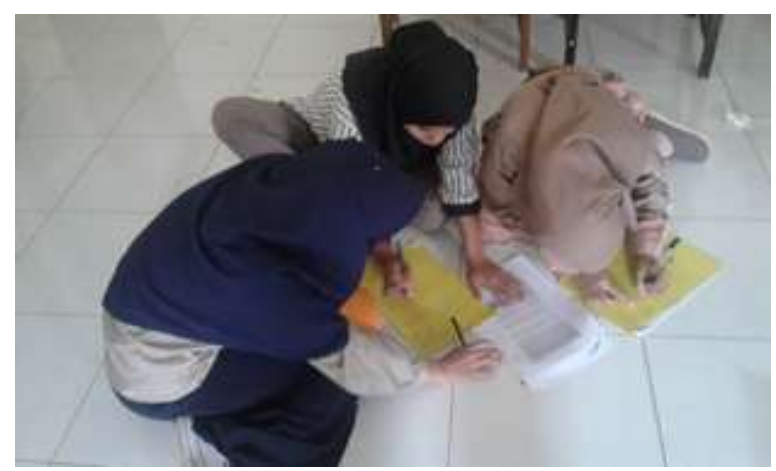

Gambar 4. Mahasiswa mengidentifikasi permasalahan sosial

Mahasiswa mampu menemukan pendapat mereka secara bebas dan mampu mengidentifkasi permasalahan-permasalahan yang dikemukakan secara objektif.

b. Komunikasi mahasiswa cukup aktif

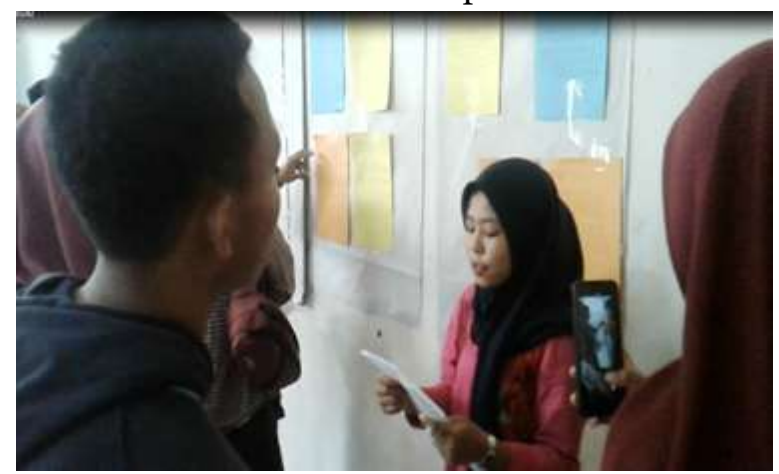

Gambar 5. Mahasiswa kelompok asal sedang menjelaskan kepada kelompok tamu

Dalam proses pembelajaran tersebut mahasiswa mampu menjelaskan kepada temannya tentang sub topik pembelajaran dengan pendapat mereka sendiri, kemudian dalam proses tersebut bahasa dan pesan yang disampaikan cukup tepat, jelas dan sinkron terhadap apa yang dipertanyaan di saat proses didkusi.

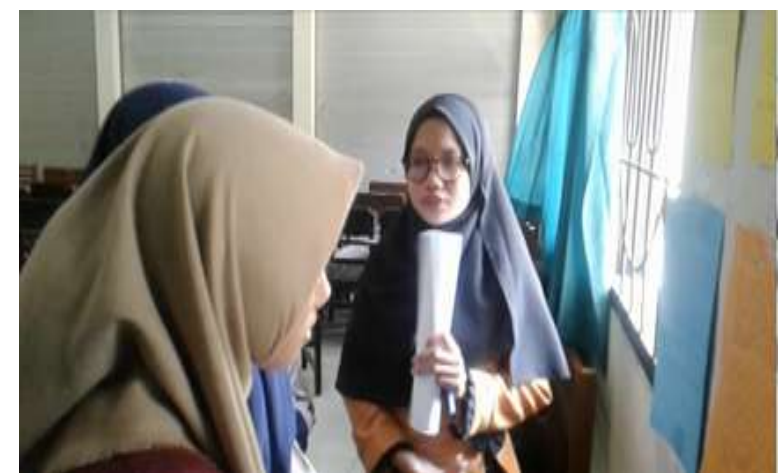

Gambar 6. Mahasiswa menjelaskan materi masalah social di lingkungan sekitar terkait IPS

Demikian juga kelompok lainnya sangat aktif baik komunikasi antara kelompok asal dan kelompok tamu sangat aktif saling mencurahkan pendapatnya tentang topik seperti masalah-masalah social yakni korupsi, kemiskinan, kriminalitas dan bencana alam. Materi IPS sangat erat kaitannya dengan data factual sehingga dalam berdiskusi mahasiswa mampu mengolaborasikan antara teori dan kehidupan nyata. Hal inilah yang mendorong berpikir kritis mahasiswa cukup tajam karena sesuai dengan pengalaman mereka.

c. Kemampuan berpikir kritis mahasiswa

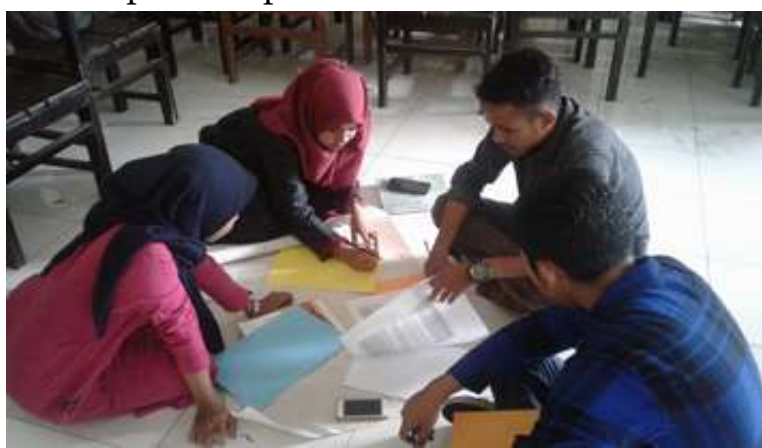

Gambar 7. Mahasiswa sedang berdiskusi dan mengidentifikasi masalah social kemudian dituliskan pada lembar kegiatan

Kemampuan berpikir kritis mahasiswa dapat dilatih melalui pembelajaran PDS di perkuliahan dengan mengembangkan metode pembelajaran, media pembelajaran dan memberikan alat peraga berupa modul pembelajaran yang dilengkapi latihan soal dan tugas mahasiswa. Perangkat tersebut digunakan untuk membina berpikir kreatifitas mahasiswa dalam mengidentifikasi, menjelaskan, merumuskan dan menggambarkan apa saja yang telah diperintahkan dalam modul pembelajaran tersebut. 


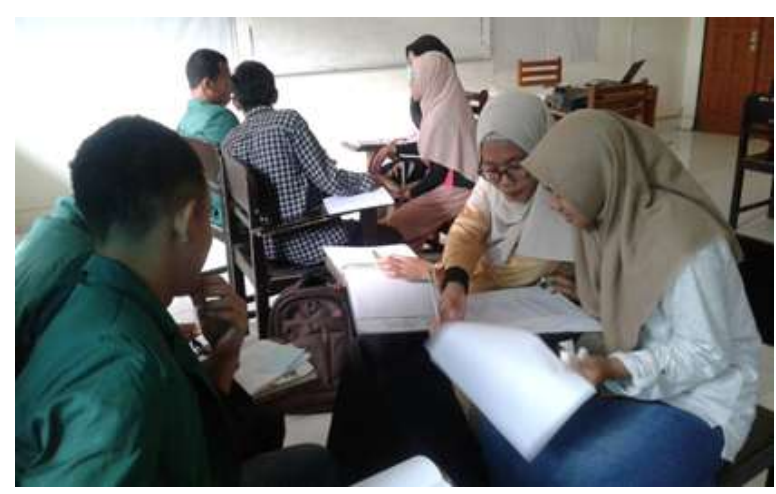

Gambar 8. Mahasiswa sedang manganalsis LK

Selain itu, proses pembelajaran juga perlu diberikan kesempatan mahasiswa untuk berpikir, berkomunkasi dan berkolaboratif sesuai dengan pembelajaran abad 21 yakni berpikir kritis, kreatif, kolaboratif, komunikatif dan menyenangkan. Hal tersebut yang dilakukan dalam pelaksanaan PDS di perkuliahan.

d. Tanggapan mahasiswa terkait pelaksanaan PDS di perkuliahan

Tanggapan mahasiswa terkait pelaksanaan PDS di perkuliahan cukup positif dimana menurut mereka menyatakan bahwa

"saya sangat senang dengan pembelajaran PDS ini karena metode yang digunakan oleh dosen adalah metode The Power Two One dan the Change of Exchange dengan bantu berbagai media pembelajaran berupa proyketor, median gambar, LK ini sangat membantu kami untuk melatih berpikir kritis, komunkatif, kreatif, mental untuk dapat menyampaikan isi pikiran kami berupa konsep-konsep sosial" (Wawancara, Zulai Pani, 25 Oktober 2019).

Sementara mahasiswa lainnya menjelaskan bahwa "Pembelajaran semacam PDS ini dapat memotivasi kami untuk terus berpikir kreatif dalam menjawab berbagai Lembar Kegiatan berupa LK yang berisikan materi, rangkuman, soal latihan. LK tersebut sangat membantu kami dalam menemukan pendapat dan mampu menjawab pertanyaan berbagai kelompok. Metode the change of exchange cukup menarik karena kami sebagai kelompok asal akan menjelaskan materi yang telah kami kerjakan kemudian kami menjelaskan kepada kelompok pendatang. Kemudian kelompok pendapat tersebut menanggapai apa yang kami sampaikan. Selainnya itu anggota kelompok berjumlah 4 orang ini akan membagi tugas yakni ada yang bertugas menjelaskan da nada yang bertugas sebagai tamu kepada kelompok lainnya. Ini saya piker cukup menarik dan membuat kami cukup senang" (Wawancara, Aswin, 25 Oktober 2019).
Demikian juga pendapat lainnya yang menyatakan bahwa

"menurut saya pribadi, kita bertanggung jawab secara pribadi, mempertanggungjawabkan kepada kelompok yang diberikan tugas. Dapat menambah kepribadian kita karena proses pembelajaran diberikan sangat variasi yakni kolaboratif metode The Power of Two, Group to Group Exchange yang merupakan pembelajaran saling tukar kelompok, saling tukar pendapat, curah pendapat dan melatih mental kami sebagai mahasiswa. Pembelajaran ini sangat bagus dan terus digunakan pada pembelajaran di kalangan mahasiswa" Wawancara, Ziah Kurniati, 25 Oktober 2019

\section{TEMUAN DAN DISKUSI}

Proses pembelajaran PDS di perkuliahan yang telah dilakukan meliputi beberapa tahapan yaitu:

Pertama, merencanakan pelaksanaan PDS bersama dosen program studi. Perencanaan merupakan tahap awal dalam menyiapkan segala sesuatu baik melihat kondisi mahasiswa, fasilitas pendukung pembelajaran, media pembelajaran yanga dipergunakan pada pembelajaran PDS diperkuliahan serta pembahasan dengan dosen-dosen program studi dengan tujuan memperbaiki kualitas pembelajaran. Karena perencanan merupakan cara awal menuju perubahan dalam perbaikan pembelajaran.

Perencanaan pembelajaran merupakan seperangkat materi dan alat yang dipersiapkan guru ketika akan mengajar dengan mengedepankan aspek afektif dan nilai-nilai karakter yang luhur dalam perencanaannya untuk diinternalisasikan ke dalam diri muridmuridnya[11]. Demikian juga lainnya menjelaskan bahwa lewat rencana pembelajaran yang telah dibuat tersebutlah seorang guru/pendidik harus mampu mengimplementasikan pendidikan karakter dalam pembelajaran yang dibuatnya[12].

Kedua, menyiapkan perangkat pembelajaran berupa RPS, RPM, media pembelajaran, dan evaluasi. Perangkat pembelajaran meruapakan salah satu indicator keberhasilan peserta didik dalam dunia pendidikan, jika perangkat pembelajaran sudah komplit maka akan mempengaruhi peningkatan kemampuan berpikir peserta didik, demikian pula sebaliknya jika perangkat pembelajaran kurang komplit maka berpengaruh kurangnya peningkatan kemampuan berpikir peserta didik.

Uraian tersebut sejalan dengan pernyataan bahwa aktivitas pembelajaran baik dengan $77,6 \%$ siswa aktif, 95\% siswa mencapai ketuntasan dengan rata-rata 80,75; bahan ajar layak digunakan dengan rata-rata $83,2 \%$ dan mahasiswa memberi respon positif terhadap buku ajar[13].

Ketiga, melakukan evaluasi. Evaluasi merupakan cara untuk mengetahuan keberhasilan suatu pembelajaran baik dilakukan secara tertulis, lisan maupun tugas. Pelaksanaan PDS diperkuliahan ini digunakan evaluasi tugas dengan mengerjakan LK secara indivisu maupun kelompok dengan diberikan setiap pertemuan. Semakin sering diberikan tugas maka semakin banyak pula pengetahuan maupun kemampuan 
mahasiswa yang telah kita ajarkan. Tujuan evaluasi ini untuk mengetahui seberapa besar kemampuan mahasiswa dalamberpikir kreatif melalui penugasanpenugasan yang telah diberikan selama proses pembelajaran.

Berikut hasil evaluasi hasil LK.1 sampai dengan LK.5 yang terbagi keldalam kelompok I, II, III, IV, dan V, dapat diuraikan dalam gambar berikut:

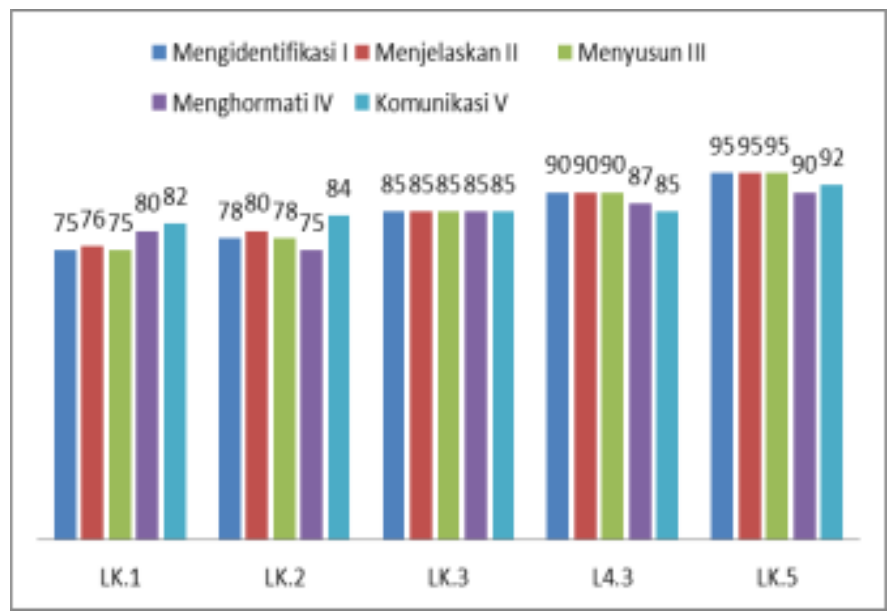

Grafik 1. Hasil evaluasi kemampuan berpikir kreatif mahasiswa

Dengan demikian rata-rata kemampuan berpikir kreatif mahasiswa cukup meningkat dalam setiap LK-LK yang telah diberikan yakni rata-rata mencapai LK.1: 77, LK.2 : 79, LK.3: 85, LK.4: 88, dan LK.5: 93. Jadi kemampuan berpikir kreatif mahasiswa berkategori sangat aktif. Hal tersebut sesuai penjelasan yang mengatakan bahwa kemampuan berpikir kreatif siswa mengalami peningkatan dari 26,67\%, meningkat menjadi 86,67\%[14]. Dengan demikian dapat disimpulkan bahwa meningkatkan kemampuan berpikir kreatif siswa dengan penerapan model pembelajaran berbasis masalah telah berhasil dilaksanakan.

Keempat, merefleksikan hasil pembelajaran PDS di perkuliahan. Refleksi merupakan kegiatan evaluasi tahap akhir dalam pembelajaran PDS yakni kegiatan yang menyarankan kepada dosen pengampu mata kuliah untuk dimintai pengalaman dan temuan-temuan baru berdasarkan proses pembelajaran yang telah dilaksanakan selama dalam kelas. Selain itu refleksi meruapakan kegiatan yang menilai kelebihan dan kekurangan proses pembelajaran PDS diperkuliahan. Kelebihan merupakan nilai positif yang duhasilkan, sementara nilai kekuarangan merupakan catatan penting untuk kedepan diperlukan adanya perbaikan baik penyiapan perangkat, media, metode, teknik dan masalah lainnya yang belum ditemukan dalam proses pemeblajaran.

Implementasi PDS di Perkuliahan telah memberikan dampak yang positif bagi kemajuan berpikir kreatif mahasiswa di Universitas Muhammadiyah Mataram hal tersebut dapat diidentifkasikan dan berdampak pada beberapa kemampuan berpikir kreatif mahasiswa tergolong sangat aktif. Karena "berpikir kreatif adalah memberikan macam-macam kemungkinan jawaban berdasarkan informasi yang diberikan dengan penekanan pada keragaman jumlah dan kesesuaian"[15][16]. Dengan kata lain, kemampuan berpikir kreatif adalah proses yang dilakukan oleh seseorang untuk mengembangkan suatu persoalan menjadi alternatif jawaban.

Selain itu juga pendapat lainnya menjelaskan pembelajaran dengan model MMP (Membaca, Menulis, Permulaan) mencapai ketuntasan, rata-rata kemampuan berpikir kreatif siswa pada model MMP (Membaca, Menulis, Permulaan) lebih tinggi dari pada rata-rata kemampuan berpikir kreatif siswa pada pembelajaran ekspositori, dan terdapat pengaruh positif keaktifan siswa pada model pembelajaran MMP terhadap kemampuan berpikir kreatif siswa[3].

Respon mahassiwa juga cukup positif dengan memberikan testimony terhadap proses berjalan pembelajaran PDS di perkuliahan yang menurut pendapat mereka mahasiswa sangat senang. Hal tersebut sesuai dengan pernyataan mereka yang menyatakan "saya sangat senang dengan pembelajaran PDS ini karena metode yang digunakan oleh dosen adalah metode The Power Two One dan the Change of Exchange dengan bantu berbagai media pembelajaran berupa proyketor, median gambar, LK ini sangat membantu kami untuk melatih berpikir kritis, komunkatif, kreatif, mental untuk dapat menyampaikan isi pikiran kami berupa konsep-konsep sosial" (Wawancara, Zulai Pani, 25 Oktober 2019).

Program Penugasan dosen di sekolah merupakan salah satu program pengabdian pada masayrakat yang bertujuan untuk mendukung tujuan dari revitalisasi LPTK antara lain, tatakelola kelembagaan yang akuntabel dan sistem manajemen modern; sistem rekrutmen calon guru yang komprehensif (termasuk seleksi bakat, minat, dan kepribadian); kurikulum dan sistem pembelajaran yang berwawasan masa depan; dukungan sarana dan prasarana (asrama mahasiswa PPG); sumber daya manusia (pendidik dosen) yang berkualitas; sekolah laboratorium \& sekolah mitra; dan system penjaminan mutu khas LPTK, serta untuk meningkatkannya kompetensi pendidik, baik dosen dan guru, dalam proses interaksi pembelajaran sesuai bidang ilmu pendidikan[4]. Demikian juga pencapaian dalam program ini diwujudkan dengan tersusunnya silabus, RPP, dan bahan ajar berbasis karakter dan adanya pengembangan bahan ajar[3].

\section{E. KESIMPULAN}

Pelaksanaan implementasi Penugasan Dosen Sekolah (PDS) di perkuliahan dapat berdampak terhadap adanya pengembangan berpikir kreatif mahasiswa civic education dalam menemukan ide, gagasan, konsep, fakta, berkomunikasi, dan berinteraksi. Sementara proses pelaksanaan Penugasan Dosen Sekolah (PDS) di perkuliahan dapat dilakukan beberapa tahapan yaitu Pertama, merencanakan pelaksanaan Penugasan Dosen Sekolah (PDS) bersama dosen program studi; Kedua, menyiapkan perangkat pembelajaran berupa RPS, RPM, media pembelajaran, evaluasi; Ketiga, melakukan evaluasi; Keempat, merefleksikan hasil pembelajaran PDS di perkuliahan. Dengan demikian, pemerintah untuk membuat regulasi untuk diberikan kepada dosen untuk mengajar di sekolah, untuk kajian selanjutnya dapat mengembangkan penugasan dosen sekolah pada eksperimen lebih besar. Jadi Penugasan Dosen Sekolah 
(PDS) sangat penting untuk digunakan baik bagi dosen maupun guru.

\section{UCAPAN TERIMA KASIH}

Tim peneliti mengucapkan terima kasih kepada Dirjen Belmawa Kemenristekdikti RI, Dekan FKIP Universitas Muhammadiyah Mataram, dan semua pihak yang telah banyak membantu dalam penyelesaikan penelitian ini.

\section{DAFTAR RUJUKAN}

[1] A. Sakban and S. Nirwana, "Pelaksanaan PDS Model Problem Based Learning Untuk Meningkatkan Pengetahuan Siswa pada Mata Pelajaran PPKn di Kelas VII SMPN 2 Labuapi Lombok Barat," in Prosiding Seminar Nasional II APPPI NTB 2018, 2018, vol. 1, no. 1.

[2] W. H. Prasetiyo, "Peningkatan Civic Skills Dan Civic Empathy Mahasiswa Melalui Citizen Journalism Project,” J. Pendidik. Karakter, vol. 8, no. 2, 2018.

[3] S. Sirojjuddin, A. Triyoso, and J. Jusmin, "Implementasi Program Penugasan Dosen di Sekolah," J. Abdimasa, vol. 2, no. 1, pp. 6-9, 2019.

[4] N. Nana, E. Surahman, and I. M. Ridwan, "Implementasi Program Penugasan Dosen di Sekolah,” DIFFRACTION, vol. 1, no. 2, pp. 1-7, 2019 .

[5] S. E. Atmojo, "Implementasi Program Penugasan Dosen Di Sekolah (PDS) Untuk Meningkatkan Kreativitas Mahasiswa Calon Guru SD Dalam Perkuliahan IPA Bervisi Sets Berbantuan APS," $J$. Educ. Technol., vol. 3, no. 4, pp. 307-314, 2019.

[6] S. H. Noer, "Kemampuan berpikir kreatif matematis dan pembelajaran matematika berbasis masalah Open-Ended," J. Pendidik. Mat., vol. 5, no. 1, 2011.

[7] D. J. Treffinger, G. C. Young, E. C. Selby, and C. Shepardson, "Assessing Creativity: A Guide for Educators.," Natl. Res. Cent. Gift. Talent., 2002.

[8] S. Zubaidah, N. M. Fuad, S. Mahanal, and E. Suarsini, "Improving Creative Thinking Skills of Students through Differentiated Science Inquiry Integrated with Mind Map.," J. Turkish Sci. Educ., vol. 14, no. 4, pp. 77-91, 2017.

[9] M. Zaidan, "Kegiatan Penugasan Dosen Di Sekolah (PDS) IKIP-PGRI Pontianak," $J$. Penamas Adi Buana, vol. 3, no. 1, pp. 1-8, 2019.

[10] S. Nadir, "Otonomi Daerah Dan Desentralisasi Desa: Menuju Pemberdayaan Masyarakat Desa," JPP (Jurnal Polit. Profetik), vol. 1, no. 1, 2013.

[11] S. Julaiha, "Implementasi pendidikan karakter dalam pembelajaran," Din. ilmu, vol. 14, no. 2, pp. 226-239, 2014.

[12] W. T. Pangestu, "Pengembangan Buku Ajar Berorientasi Pendidikan Karakter pada Mata Kuliah Pembelajaran PKn SD di Program Studi S1 PGSD," Prem. Educ. J. Pendidik. Dasar dan Pembelajaran, vol. 4, no. 1, 2016.

[13] U. Wati and D. Utama, "Meningkatkan Kemampuan Berpikir Kreatif Siswa dengan Model Pembelajaran Berbasis Masalah dalam
Mata Pelajaran Pendidikan Kewarganegaraan di Kelas VIIA SMP Negeri 2 Lamongan," Kaji. Moral dan Kewarganegaraan, vol. 1, no. 1, pp. 257-271, 2013.

[14] U. Munandar, "Pengembangan Kreativitas pada Anak Berbakat," Jakarta PT. Rineka Cipta, 2012.

[15] A. Sakban, "Penerapan Pendekatan Deep Dialog and Critical Thinking Terhadap Berpikir Kritis dan Penguasaan Konsep Siswa pada Pembelajaran Pendidikan Kewarganegaraan di SMP Negeri 7 Mataram," Universitas Negeri Makassar, 2015

[16] N. Pramudiyanti, "Keefektifan Pembelajaran Model Mmp Berbantuan Cabri 3d Terhadap Kemampuan Berpikir Kreatifmatematis Siswa Kelas X SMA Pada Materi Dimensi Tiga." Universitas Negeri Semarang, 2013. 